\title{
Radioactivity Maps of Nova Scotia
}

\author{
K.L. Ford, P.B. Holman, J.A. Grant and J.M. Carson \\ Airborne Geophysics Section, Mineral Resources Division, Geological Survey of Canada, \\ 601 Booth Street, Ottawa, Ontario K1A OE8, Canada
}

Results of airborne gamma ray spectrometric surveys flown over the province of Nova Scotia by the Geological Survey of Canada between 1976 and 1990 have been published as a series of eight colour maps at 1:2,000,000 scale (Geological Survey of Canada Open File 2375). Four of these maps are reproduced here; the Ternary Radioelement Map, Potassium (pct), equivalent Uranium/equivalent Thorium, and equivalent Thorium/Potassium ratios. Other maps, not reproduced here, are Exposure Rate $(\mathrm{uR} / \mathrm{hr})$, equivalent Uranium (ppm), equivalent Thorium (ppm), and equivalent Uranium/Potassium ratio. Most of these data were previously released as 1:50,000-scale black-line contour maps and as a series of eight, 1:500,000-scale colour radioactivity maps of Nova Scotia (Ford et al., 1989). All data were collected using $50 \mathrm{~L}$ of sodium iodide detectors flown at a nominal terrain clearance of $120 \mathrm{~m}$, with a ground speed of $190 \mathrm{~km} / \mathrm{hr}$ and a flight line spacing of $1000 \mathrm{~m}$. Uranium, thorium and potassium counts were measured over one-second intervals. Flight line data were averaged and interpolated to a $250 \times 250 \mathrm{~m}$ grid. The general principles of airborne gamma ray spectrometric surveying have been recently reviewed by Grasty $e t$ al. (1991).

Several studies (Ford et al., 1989; O'Reilly et al., 1988; Ford and O'Reilly, 1985) have demonstrated that airborne gamma ray spectrometry is a valuable aid to regional and detailed bedrock and surficial geological mapping and multielement geochemical exploration in granitic terrains similar to that of the Meguma Zone in southern Nova Scotia. The radioelement distribution patterns as measured by the airborne surveys accurately reflect the relative variations in $\mathrm{K}$, $\mathrm{U}$ and $\mathrm{Th}$ in the bedrock and surficial materials. Any interpretation for bedrock mapping applications, however, must involve an understanding of the Pleistocene geology. In areas where bedrock radioelement contrasts are reflected in associated overburden, the airborne gamma ray surveys provide excellent predictive tools for mapping both the Pleistocene and bedrock geology. In the granitic rocks of southern Nova Scotia, studies have shown that the radioelement distribution patterns are controlled by variations in magmatic differentiation and by superimposed effects of late- and/or post-magmatic metasomatism and hydrothermal alteration. The ability of the airborne gamma ray surveys to recognize areas of pervasively altered rocks or cryptic compositional zonation is an important application for granophile-element mineral deposits and, as has been shown in other areas (Charbonneau et al., 1992), some forms of precious and base metal mineralization.

Requests for map products or digital gridded or line data may be directed to any of the authors or to Publications, Geological Survey of Canada, 601 Booth Street, Ottawa, Ontario K1A 0E8; Telephone (613) 995-4342. The accompanying geological map was supplied by Dr. D. Kontak, Nova Scotia Department of Natural Resources.

Charbonneau, B.W., Shives, R.B.K., and legault, M. 1992. Application of gamma spectrometry to gold exploration. In Geological Survey of Canada, Minerals Colloquium, Program with Abstracts, January 22-24, 1992.

Ford, K.L. and O'Reilly, G.A. 1985. Airborne gamma ray spectrometric surveys as in indicator of granophile element specialization and associated mineral deposits in the granitic rocks of the Meguma Zone of Nova Scotia. In High Heat Production (HHP) Granites, Hydrothermal Circulation and Ore Genesis. Institution of Mining and Metallurgy, St. Austell, Cornwall, England, pp. 113-133.

Ford, K.L., Carson, J.M., Grant, J.A., and Holman, P.B. 1989. Radioactivity Maps of Nova Scotia. Geological Survey of Canada, Geophysical Series Map 35006G, Scale 1:500,000.

Ford, K.L., MacDonald, M.A., Finck, P.W., Boner, F.J., Ha M, L.J., Horne, R.J., Corey, M.C., and Graves, R.M. 1989. Airborne gamma ray spectrometry, and bedrock and surficial geology of the Davis Lake Pluton. In Mines and Minerals Branch, Report of Activities, 1989, Part A. Edited by D.R. MacDonald and K.A. Mills. Nova Scotia Department of Mines and Energy, Report 89-3, pp. 169-171.

Grasty, R.L., Mrllander, H., and Parker, M. 1991. Airbome gamma ray spectrometer surveying. International Atomic Energy Agency, Technical Reports Series No. 323, Vienna, $97 \mathrm{p}$.

O'Reilly, G.A., Corey, M.C., and Ford, K.L. 1988. The role of airborne gamma ray spectrometry in bedrock mapping and mineral exploration: case studies from granitic rocks within the Meguma Zone, Nova Scotia. Maritime Sediments and Atlantic Geology, 24, pp. 47-60.

Geological Survey of Canada Contribution No. 12892 


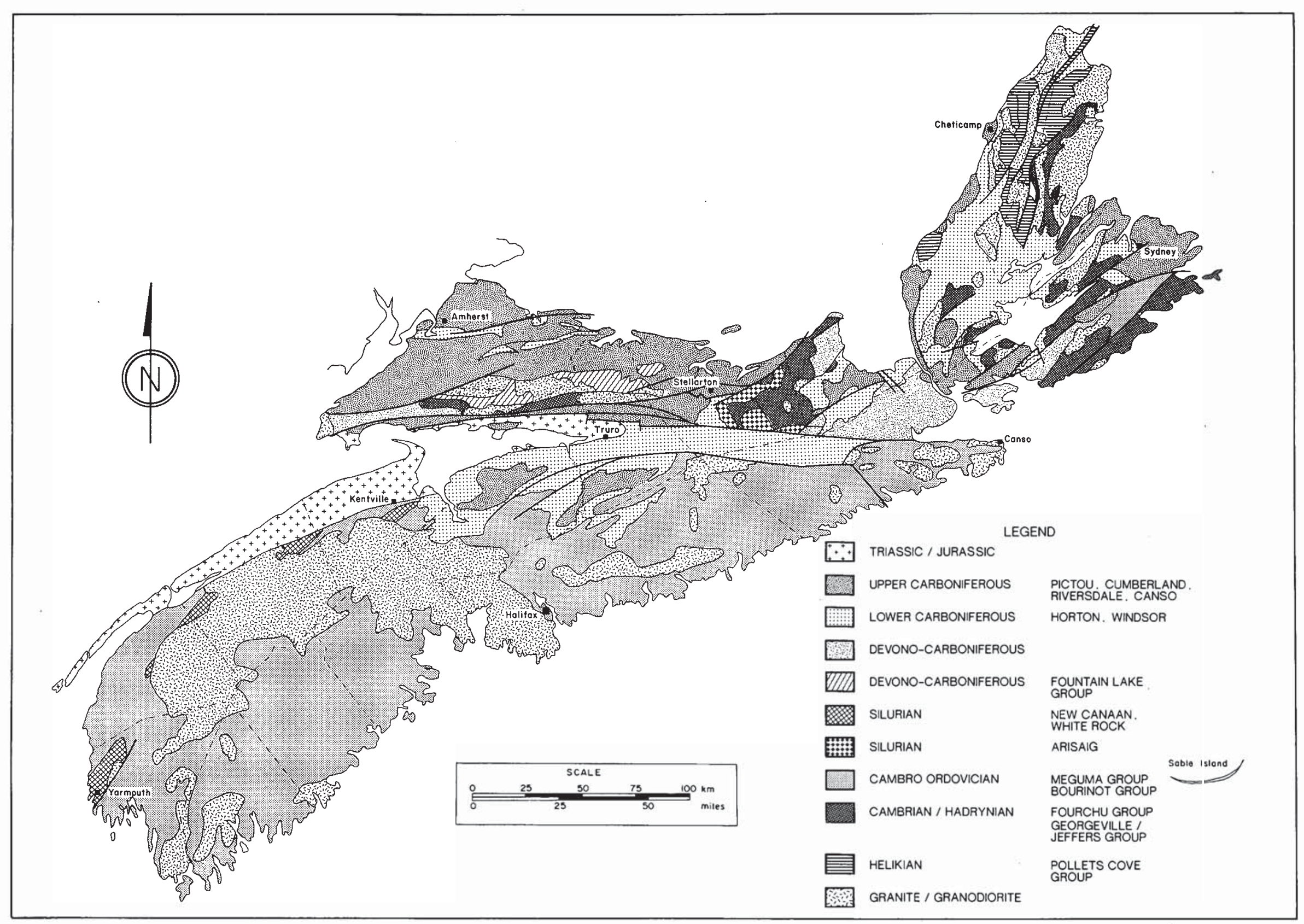




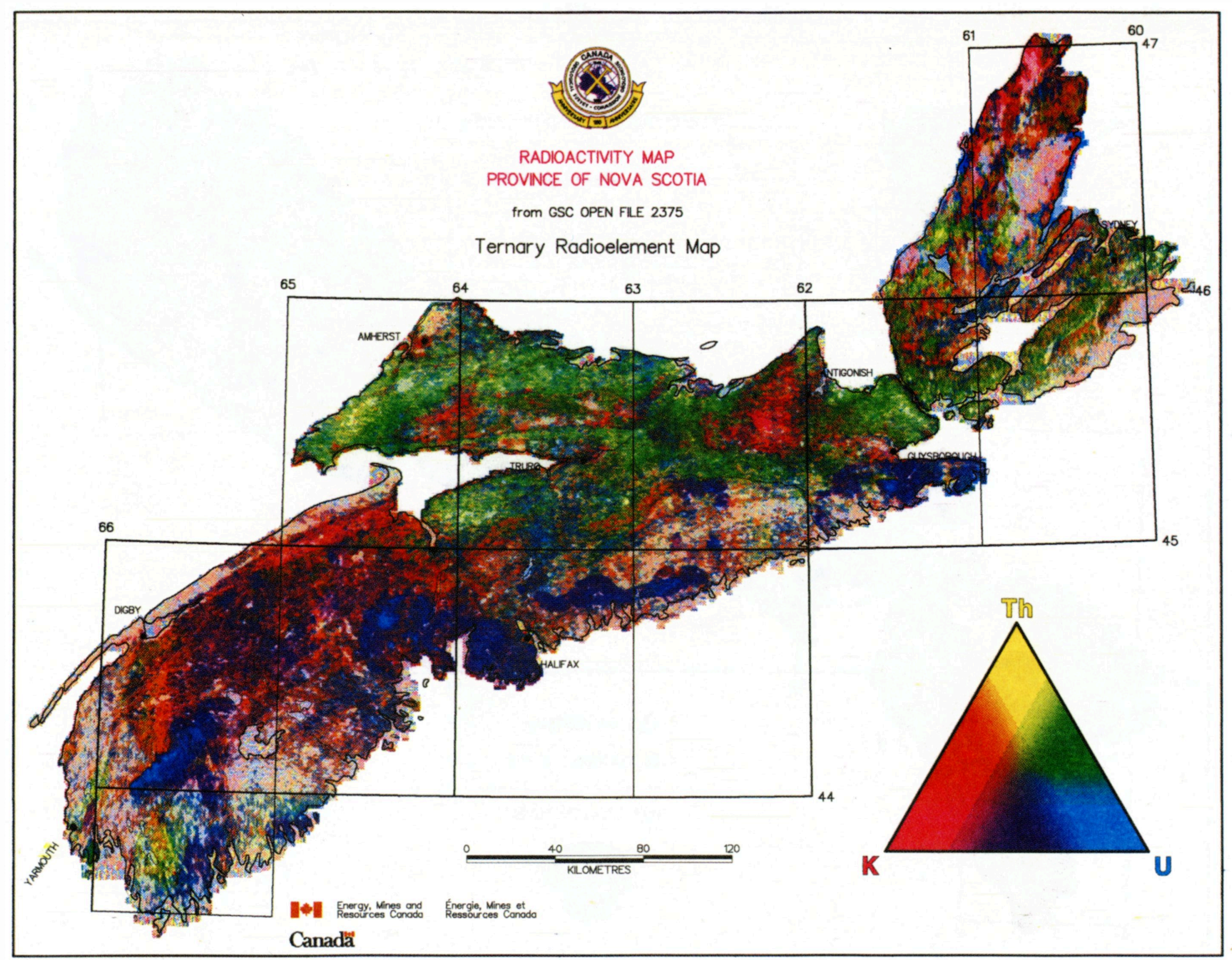




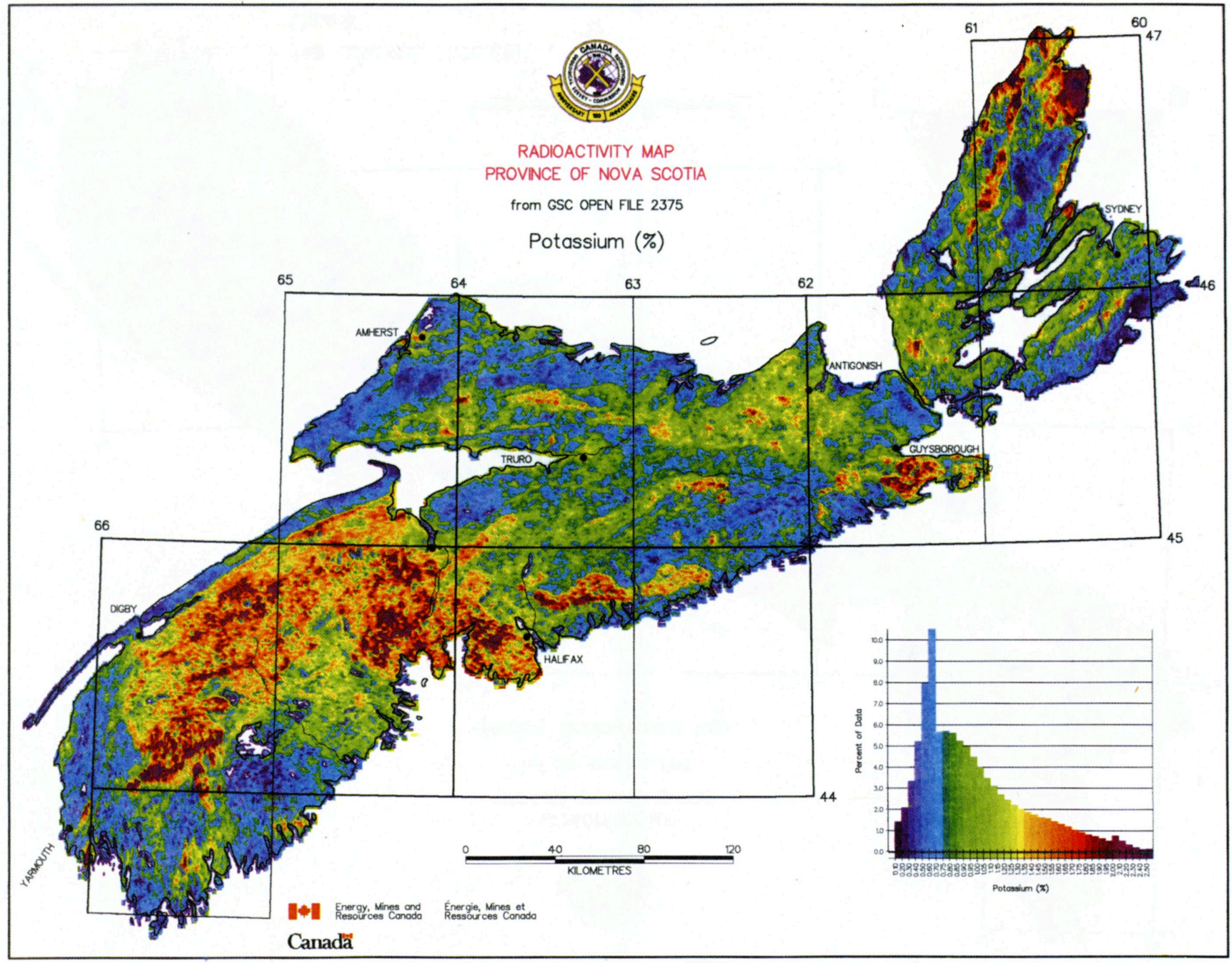




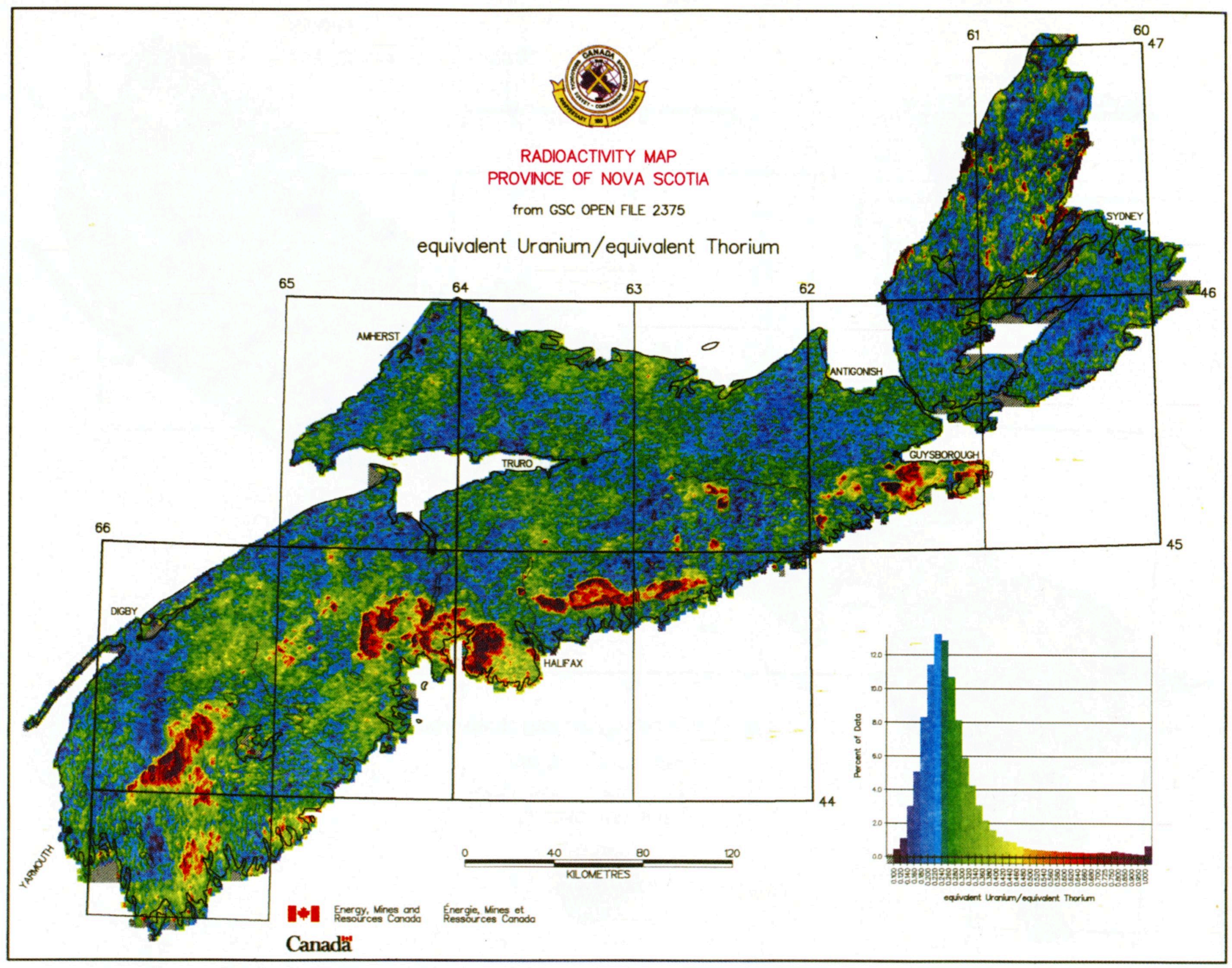




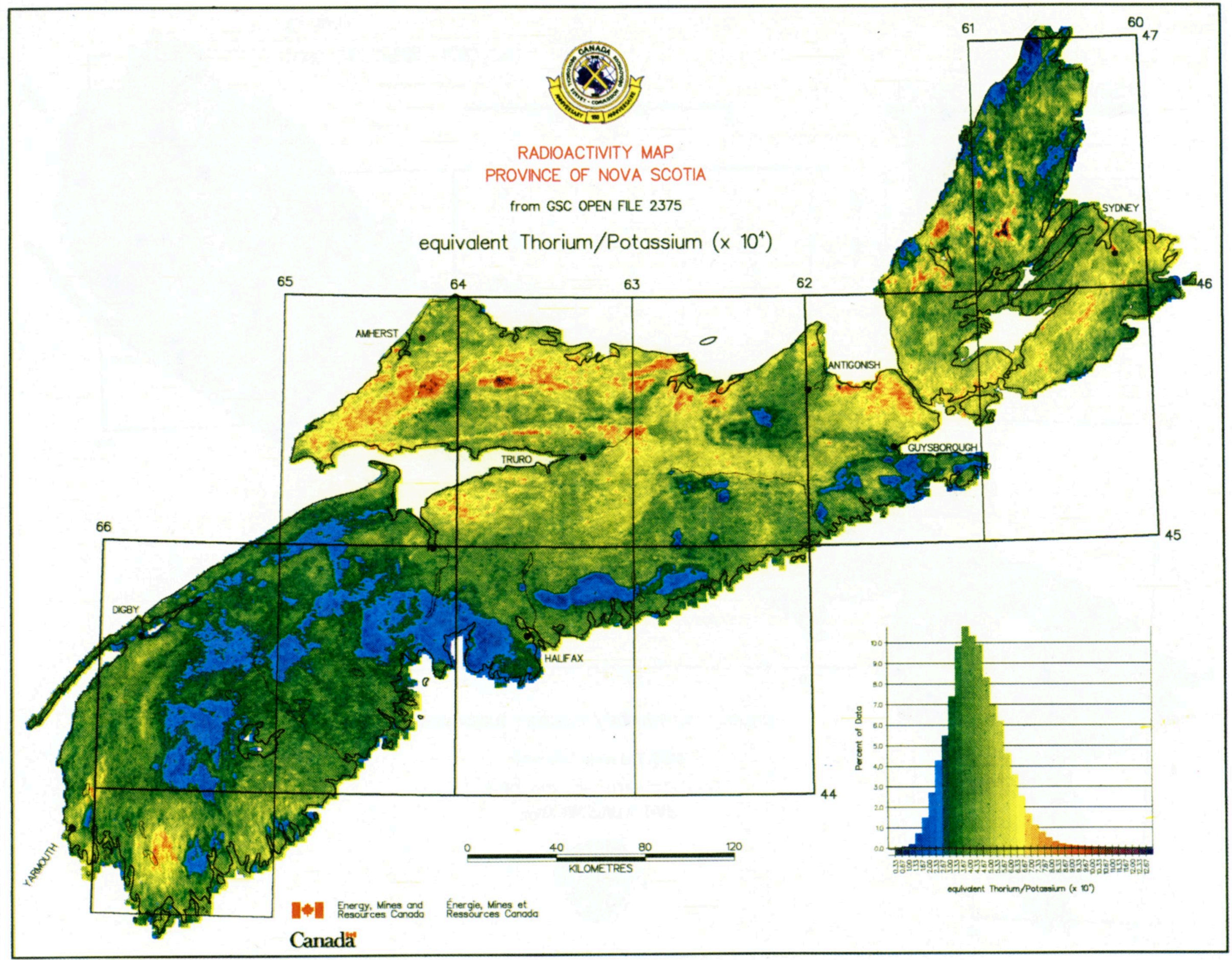

